О. І. Дрогайщев

\title{
ВІДНОСНЕ ВЖИВАННЯ ЧАСОВИХ ФОРМ ДІЕСЛОВА В УКРАЇНСЬКІЙ ТА НІМЕЦЬКІЙ МОВАХ
}

Дрогайцев О. І. Відносне вживання часових форм дієслова в українській та німецькій мовах.

У статті розглянуто питання про відносне вживання часових форм дісслова в українській та німецькій мовах, про їх спільність і відмінність.

Ключові слова: часові форми дієслова, відносне вживання часових форм дієслова.

Дрогайцев А. И. Относительное употребление временных форм глагола в украинском и немецком языках.

В статье рассматривается относительное употребление временных форм глагола в украинском и немецком языках, их общность и различие.

Ключевые слова: временные формы глагола, относительное употребление временных форм глагола.

Drogaytsev O. I. Relative usage of tense form of the verb in Ukrainian and German.

In the research the relative usage, quantity and distinction of tense forms of the verb in Ukrainian and German are examined.

Key words: tense form of the verb, relative usage of tense form of the verb. 
Важливою граматичною категорією в українській та німецькій мовах є дієслівна категорія часу. Граматична категорія часу (das Tempus) у німецькій мові виражає часове відношення дії до моменту мовлення або до моменту, коли відбувається інша дія [5, с. 19].

Відмінність уживання часових форм українських та німецьких дієслів полягає насамперед у їх різній кількості. В українській мові для вираження часових значень існує три часові форми, у німецькій шість. Окрім того, категорія часу в німецькій мові ускладнена значенням відносного часу. В українській мові дієслівні форми можуть виражати як абсолютне, так i відносне значення i не $\epsilon$ диференційованими згідно 3 їхніми функціями. У німецькій мові необхідно розрізняти часові форми дієслова у простому і складному реченні. Так, у складному реченні часова форма події залежить від іншої, відповідно до якої вона визначається.

До відносних часових форм у німецькій мові належать Plusquamperfekt (відносний минулий час) та Futurum-II (відносний майбутній час) [1, с. 198]: Bei seiner Ankunft hatte der Mechanicker sein Auto schon repariert (Plusquamperfekt) - До його прибуття механік вже відремонтував його автівку; Bis morgen wird der Schnee wieder geschmolzen sein (Futur-II) - До завтра сніг знову розтане.

В українській мові відносне використання часу трапляється в підрядних реченнях при дієсловах мовлення або почуття, думки. Подія в таких реченнях орієнтується на дію в головній предикативній частині. Наприклад: Вона стверджує, щзо виконає свою обіиянку. Співвідносність дії з моментом мовлення в реченні може визначати при цьому пряме або відносне вживання часових форм дієслова. Найбільш виразно це відображає теперішній час як форма граматичної категорії часу дієслова, прямим значенням якої є відношення часу дії або стану до моменту мовлення (читаю, розмовляю, сиджу).

Теперішній час в українській мові може означати: 1) постійну дію, не обмежену будь-якими часовими рамками; 2) дію, що мовець оцінює як постійну, незмінну; 3) дію, яку мовець не пов’язує з конкретним часом. При прямому вживанні форми теперішнього часу мають два значення: 1) теперішній актуальний - основне значення теперішнього часу; 2) теперішній неактуальний - передає дію, яка розпочалася до моменту мовлення, відбувається під час мовлення і триватиме після розповіді про неї. У вживанні неактуального теперішнього виділяється значення теперішньо-минулого і теперішньо-майбутнього часу. Крім свого основного значення, яке протиставляється минулому й майбутньому, теперішній час в українській, як і в німецькій мові, може вживатися у 
значенні майбутнього. При позначенні майбутньої дії за допомогою часової форми теперішнього часу (Präsens) у німецькій мові це часто виражається поєднанням дієслова 3 прислівниками 3 часовим значенням - morgen, übermorgen, bald, в українській - завтра, nіслязавтра, незабаром і т. ін. Наприклад: Übermorgen findet die geplante Konferenz statt - Післязавтра відбудеться запланована конференція; Morgen besuche ich im Krankenhaus meine alte Oma Завтра я відвідаю в лікарні мою стареньку бабусю.

При розгляді відносного часу в німецькій мові необхідно враховувати складність значення німецьких відносних часових форм у зв’язку з такою категорією дієслова, як завершеність. Відносний час завершеного дієслова відображає передування і завершеність дії, тоді як відносний час незавершеного дієслова виражає лише передування дії [4, с. 224]. Отже, у відносному часі завершених дієслів простежується спорідненість з українською формою доконаного виду. Наприклад: Wenn du das Buch bis zu Ende liest, werde ich dir ein neues vorbereitet haben - Коли ти прочитаєш книгу до кіния, я приготую тобі нову.

При відносному вживанні часових форм дієслова в німецькій мові передування дії в теперішньому часі передається через Präsens + Perfekt: Ich weiss nicht, wie ich in mein Zimmer gekommen bin (E. M. Remarque); Hugo kommt! Ich habe ihn seit Idas Tod nicht mehr gesehen (I. Noll).

Передування дії в минулому часі передається через Präteritum + Plusquamperfekt: Martha öffnete die Tür, da sie die Klingel auf dem Korridor gehört hatte (B. Kellermann); Ich dachte an den Zettel, den ich morgens in der Werkstatt geschrieben hatte (E. M. Remarque).

Futurum-II передає у складному реченні передування дії в майбутньому часі: Sie rechnen aus, wieviel heute jede Minute über die Brücke gehen und wie viel in zehn Jahren über die Brücke gegangen sein werden (H. Böll); Wenn sie ihr Haus in San Francisko betreten haben wird, dann ist dieses Kapitel abgeschlossen (U. Danella) [2, c. 32].

У німецькій мові відносно можуть вживатися презентні форми умовного способу дієслова (Präsens Konjunktiv, Perfekt Konjunktiv, Futurum Konjunktiv).

Präsens Konjunktiv передає одночасність подій у головній та підрядній предикативних частинах: Mein Bekannte schreibt mir, dass er seinen Urlaub auf Krim verbringe - Мій знайомий пише, щэо проводить свою відпустку у Криму.

Передування дії в підрядній предикативній частини стосовно головної передає Perfekt Konjunktiv: Mein Bekannte schreibt mir, dass er vor kurzem Jalta besucht habe - Мій знайомий пише, щчо недавно відвідав Ялту. 
Послідовність подій у підрядній та головній предикативних частинах відображає Futurum Konjunktiv: Mein Bekannte schreibt mir, dass er bald nach Kirovograd fahren werde - Мій знайомий пише, шэо скоро поїде в Кіровоград.

В українській мові, на відміну від німецької, умовний і наказовий способи взагалі не мають часу [3, с. 133], а структура складного речення не передбачає узгодженості в часі між головною і підрядною предикативними частинами.

У німецькій мові відносний час вживається лише при наявності передування однієї дії іншій, при цьому в кожному реченні всі дії відображаються різними часовими формами, в українській мові однією формою.

Безумовно, головними засобами вираження часу в німецькій та українській мовах є часові форми дієслова. Але поряд із ними наявні також інші шляхи відображення часового значення, зокрема й відносного, які відіграють у реченні досить важливу роль. Так, у німецькій мові за допомогою модальних дієслів sollen (мyсuти) та wollen (xотітu) може передаватися майбутній час - Ich will auf dich warten, bis du kommst - Я чекатиму, поки ти прийдеш; Du sollst noch sehen, womit das enden wird - Ти ще побачиш, чим це закінчиться. Значення часу в німецькому реченні може передаватися прислівниками (Partizipien) неперехідних дієслів - Das schlafende Kind liegt in seinem Bett (Partizip-I); Der geschriebene Brief liegt auf dem Tisch (Partizip-II). Відіграють свою роль при відображенні часу також темпоральні сполучники als, wenn, nachdem, bevor: Als ich die Schule absolviert hatte, besuchte er unsere Familie zum ersten Mal; Nachdem wir diese Aufgabe gemacht haben, gehen wir spazieren. Засобами вираження часу в реченні можуть виступати прикметники (die morgige Aufgabe, das vorige Jahr), словоутворювальні префікси та суфікси (der Präsident - der Expräsident, operativ - postoperativ), іменники (am Morgen, die Woche, die Vergangenheit).

\section{Література}

1. Admoni W. Der deutsche Sprachbau / W. Admoni. - М. : Просвещение, 1986. - 333 c.

2. Арсеньева М. Г. Deutsche Grammatik = Немецкая грамматика. Версия 20 : [учебное пособие] / М. Г. Арсеньева, Е. В. Нарустранг. - СПб. : Антология, 2012. - 544 с.

3. Єрмоленко С. Я. Українська мова : короткий тлумачний словник лінгвістичних термінів / С. Я. Єрмоленко, С. П. Бибик, О. Г. Тодор. - К. : Либідь, 2001. - 221 с.

4. Jung W. Grammatik der deutschen Sprache / W. Jung. - СПб. : Лань, 1996. - 517 c.

5. Смеречанський Р. І. Довідник з граматики німецької мови / Р. І. Смеречанський. К. : Либідь, 1989. - 217 с.

Стаття надійшла до редакції 09.11.2013 p. 